\title{
NATIONAL/DOMESTIC BUSINESS EXPECTANCIES TOWARDS THE EMPLOYMENT OF GRAPHIC DESIGNERS: FINDING JOBS IN TURKEY, ANALSIS ON PROFESSIONAL JOB ADVERTISEMENTS THROUGH WEB SITES
}

\author{
Cem GÜZELOĞLU
}

\begin{abstract}
Graphic design is an expertise which is benefited from in the various production processes in many industries. Graphic designers, beyond applying the existing design patterns, specialize in transferring their individual talents and creative thoughts into monetary value. In each industry, the work output expected from the expertise is different. For this reason, training, competence and talent perception regarding the graphical design expertise changes from industry to industry. With this study, by analyzing the advertisements in the job advertisement sites in Turkey according to industries, the businesses expectancies of expertise has been aimed to be set forth. The research, has been structured in the exploratory research pattern. The sites have been searched using keywords such as "Graphic designer" and "Visual communication designer" and the job adverts, published between the dates January 2016-2017, were collected as data. In this context, since the business approaches is of importance for employment in the professional field, the criterion in the job advertisements were examined and some of them were analyzed comparatively. With this study, industryspecific expectancies are going to be analyzed moving from the characteristics of job advertisements.
\end{abstract}

Keywords: Graphic Design, Graphic Designer, Graphic, Job Advertisements

JEL Classification: Z11,

\section{GRAFIK TASARIMCI ISTIHDAMINA YÖNELIK ULUSAL/YEREL IŞLETMELERIN BEKLENTILERI: TÜRKIYE'DE IŞ BULMA WEB SITELERI ÜZERINDEN MESLEKi iş ILANLARINA YÖNELIK ANALIZ}

\section{Öz}

Grafik tasarım birçok sektörde üretim süreçlerinin çeşitli aşamalarında yararlanılan bir uzmanlıktır. Grafik tasarımcılar, var olan tasarımları uygulamanın ötesinde kişisel yeteneklerini ve yaratıcı düşüncelerini parasal değere dönüştürmek üzere uzmanlaşmaktadır. Her sektörlerde uzmanlıktan beklenen iş çıktıları değişmektedir. Bu nedenle grafik tasarım uzmanlığına ilişkin eğitim, yetkinlik ve yetenek algısı da sektörden sektöre farklılaşmaktadır. Bu çalışma ile Türkiye'de iş ilanı sitelerindeki sektörel ilanlar analiz edilerek, işletmelerin uzmanlıktan beklediklerini ortaya konması amaçlanmıştır. Çalışma, keşfedici araştırma deseninde yapılandırılmıştır. Siteler "Grafik tasarımcı" ve "Görsel iletişim tasarımcısı" gibi anahtar kelimeler kullanılarak arama yapılmış ve Ocak 2016 -2017 tarihleri arasında yayınlanmış ilanlar toplanmıştır. Bu bağlamda işletmelerin yaklaşımları mesleki alanda istihdam için önem taşıdığı için ilanlardaki kriterler de incelenmiş ve bazıları ise karşılaştırmalı olarak analiz edilmiştir. Bu çalışma ile iş ilanları özelliklerinden yola çıkarak, alana dair sektörel beklentiler analiz edilmeye çalışılacaktır.

Anahtar Kelimeler: Grafik Tasarım, Grafik Tasarımcı, Grafik, Iş ilanları

JEL SInıflandırması: Z11

\footnotetext{
${ }^{1}$ c.guzeloglu@gmail.com
} 


\section{Literature}

Graphical design concept, when considered as of its characteristics, and its existence has been dated back to the firs ages of humanity, by many scholars. Although the visual works' quality and its media does not look similar to modern graphical design products, they conceptually match. For most of the visual products that are produced in our time, graphical design is considered as the most important constituent. Graphic design comes our way as a design discipline, which is actively used in many industries, including not only advertising; but also textile, information technologies, packaging, multimedia, education, cinema etc.

A human leaps to the process of communication with his/her environment beginning from the day he/she is born. This start is a constant interaction that is going to continue from birth until death. Every reflection that reaches to the person from the physical and social environment brings together a perception concept, every thought and act has a reflection on the lifestyle, physical and social environment. All of these reciprocal reflections makes up the phenomenon of fundamental communication. These reflections, which we define as communication, generally come to life with the help of our emotions. The most influential ones among these are; visual communication and auditory communication (Uçar, 2004: 16). A similar approach to this can be seen in the statement of John Berger in his book Ways of Seeing (2005:7) that the ability to see comes before speech. The child learns to look and identify before learning how to speak. However, in other words, seeing comes before words. In the world surrounding us, we find our own place by seeing. This approach shows the value of the visual communication element in human life. Graphic design takes an active role in the problem resolution part in the communication dimension of the concept visual communication which is situated pretty much in the centre of life.

In the social life which was turned upside down by the industrial revolution, huge gaps occurred between material life and spiritual needs. In order to resolve this issue, as a consequence of the effort to resettle the human's union with his/her natural environment, graphical design, architectural design, product design etc. design arts were given birth (Arıkan, 2008:9). Thus, new professions were formed and in parallel with the products that are produced in this field, theoretical backgrounds were generated. On the other hand, ecoles were born in the national or international scale, interactions have been experienced and new approaches have been developed. One of the new professions that was introduced to this world is the graphic designer. According to Öztuna (2007: 10-11), graphic design consists of many fields such as; package design, environmental graphic, informative graphic, digital-conventional illustration, press/media publishing graphic, web design, fashion graphic, typography, motion graphic etc. To be able to internalize graphic design in a good fashion and to create a more influential design, the fundamental elements and principles of design should be conceived and comprehended.

It is essential to explain the words "graphic designer" or "visual (communication) designer", which are going to be frequently used in the study. Countless references have been made to this group of profession in many sources within this context. The visual designer concept, which is frequently used in our day, can, in some instances, be used instead of the graphic designer concept too. The term graphic designer actually derives from desktop publishing. Graphic designer is the person who brings together words or visual elements in a way which would form a visual communication. These elements are presented within an audio-visual equation that could be resolved by the audience. Graphic designer is both a message conveyor and organize. Graphic design is the function of reflecting the communication enabling message in a correct and simple way (Becer, 1999: 36). Graphic designer structures a communicative message creatively and aesthetically at the same time. The designer tries to attain functionality and aesthetic balance of the work he/she does, in an optimum level (Selamet, 2012: 140). Designers produce an interactive work with other professional disciplines in order to resolve the visual problem in hand, by using the principles and elements of design. For graphic designers, following up digital technology and many innovations that come along, due to their expanding work spectrum and their improving 
skills, perhaps it is more appropriate to use the concepts visual designer or visual communication designer. Visual design, which is still a new design discipline in our country, is still showing differences as of its professional status within the sector that involves conceptual incomprehensibility. In a movement of renewing its structure dating back to a complicated and conventional background, visual design as a term, can be interpreted as a post-modern discourse developed within the profession. According to Selamet (2011:241), in this approach, graphic design had a more artistic structure regarding the graphic reproduction techniques, and this approach was identified as "graphic arts". In the aftermath, especially with the original edition solidifying its place under art as a branch, the term "graphic design" was clarified and adopted. Graphic design became integrated with design, after getting away from art as "the resolution to visual communication problems." The outcomes of graphic design, were products that were reproduced by printing on two dimensions. In the later 20th century, the development in graphic design and production technologies was at such a pace that, the products to be considered within this scope went beyond just two dimensional and printed products. After web design, motion graphic, video, audio, television, cinema and architecture was involved, in other words, when third and fourth dimensions were added upon the second dimension, the term "graphic design" became inadequate and "visual communication design" phrase came into use.

Individuals, being bombarded by visual images in nearly every minute of their lives, lose touch with their perceptions in time. Especially for visual/graphic designers, it is considered a highly difficult process to produce selective work under this intense bombardment. Therefore, visual designers have to be individuals, who are systematic, able to follow the tendencies of the period they are in, and whose social and visual intelligence is high. It is observed that designers, who have the concern of producing a work of art, especially at this period where consumption is intense, may have to quit their personal vision or give up on their aesthetical concerns.

According to Ellen Lupton's view (2012:6), the purpose of the theory comes from the question "Why?" Therefore, the question of how should be asked in order to form the design of a visual. This process is also related to the application process of a visual design. This process has a continual systematic. Graphic designers, perhaps when considered in terms of advertisement as the primary field of work; constitute the skeleton of the campaign or advertisement with the directions of advertisement/copy writer and art director in the light of the briefing coming from the employer. These drafted ideas that come to life are given to the graphic designer to form the visual side of the campaign or advertisement. Graphic designer, then gathers all this information, benefiting from visual elements and discourse factors, arranging them in a systematical hierarchy, and directs this to the related media through the agency trafficker to reach at the advertisement's consumer. This process constitutes the centre spot of visual design management. Because the question is oriented at "How?" The basis of the question "How?" the design should be done, is the question "How?" the visual or narrative elements should be used in the design of the advertisement. Therefore, the birth of creative idea is related to the designer knowing how to use what. In this respect, the education received by the designer creates a background for the products he/she is going to produce. The designer is going to put into practice the intended message or the visual problem to be resolved, with the work he/she is going to do. Graphic designer, as was mentioned before, acts in the light of the graphic design principles for the aesthetical resolution method while approaching at the design problem in this process. Generally, while designers who received an academic training in the field follow these approaches, in the productions of the individuals who venture in this field through courses, training videos or master-apprentice relationship, these concepts are rarely seen. The proper usage of graphical elements and the concern for a message, is a reflection of the intellectual accumulation and education. In graphic design or in similar departments, the individual handles art, design, philosophy, sociology and communication classes in a holistic view, and goes through a multi-versatile education phase. However, institutions that give training under the name of "graphic design course" in our country, can not go beyond computer programming, and most of the time, they stay in the level of teaching prefaces. Yet, the 
software used are only in the quality of an instrument used in graphic design production techniques, just like a pen or a brush. It is assumed that reaching to a conclusion is possible with the proper usage of graphic design principles and elements.

Meanings and feelings that every design element involves, cause cognitive changes on the consumer through the usage of design elements one by one or all together. The effort to locate and motivate the images in the consumer's mind, is put into practice through the designer's usage of the proper data. Likewise, the negative consequences caused by a successful idea being applied in a bad practice, were seen in many of the previous academic work conducted. Therefore, one should not expect success from an advertisement that had lost its visual attractiveness and meaning. The implementation of a successful design is related to the designer's education and artistic background. The designer should be a person, who digested the artistic, cultural and historical context of the present era, and who can actively be creative.

The history of graphic design in our country is generally related to the Republic. However, graphic design resolutions are not only related to printing technologies, but also heavily dependent on the visual communication problems. The technological part of the profession is just a subtitle of the whole and is constant in historical and modern examples, so that the graphic design can be done without activating the printing technologies (Akdenizli, 2005: 114). With this approach, although the graphic arts production in our country can be depended on the times before the Republic era, in Akdenizli's academic view (cited 2017), the field of graphic design in our country has started to exist as a branch of design when the poster workshop was opened in 1927 and Eric Weber was brought about with the efforts of Namık İsmail the principal of Sanayi-i Nefise School, which was established in 1883, where academic education is given ever since (Ersel; 2014,88). In modern Turkey, designers who graduate by receiving academic education in the related field, find the chance to be employed in various industries. Designers who receive academic education, venture into the sector acquiring artistic and aesthetical perspectives as well as intellectual assets. However, the reality of our country should be taken into consideration. In this occupational group, some personal traits or skills are also sought for. With the help of some vocational courses or educational packages other than academic education, even through online tutorial videos, individuals begin to work in the sector, having acquired skills. Thus, there are also individuals who have not received academic education, but still want to work in this occupational field in the sector.

\section{Research Design and Methodology}

In this occupational group that creates out of nothing as of its nature and transforms abstract thought into a concrete form, the requirement of important factors in finding jobs is observed beyond creativity. Indeed, the employment of workers, which is among the duties of the public employment office, was transferred into the internet environment with the development of communication technologies, and websites that carry out specific works in this field were actively put into practice in our lives. With this study, by analyzing the job ads in the employment web sites that are actively used in Turkey, it is aimed to establish and determine the expectancies of businesses from the profession. By considering the feature of actively publishing ads in the aforementioned web sites, the related job adverts were analyzed in the sites kariyer.net, secretcv.com and yenibiris.com which broadcast in Turkish. When the job search sites and public employment office web site were compared, job adverts in many cities of Anatolia were come across in the web site of the public employment office, in the job search sites, the adverts were mostly in the areas that are densely populated and highly industrialized. Yet, the information regarding the institutions in the adverts published by the public employment office, since expectations towards employment and more specific advert info are not present, therefore can't be analyzed, it was excluded. However, for similar examples and research, job employment demand distribution by cities etc. is the subject of research, the data with regard to the institution should also be taken into consideration. 
This research was structured in the quantitative research design as an explorative model in the light of the data collected from the abovementioned websites. The collected quantitative data were analyzed comparatively with SPSS. Besides, some factors were analyzed by per cent, and they constitute a basis for quantitative discourse used in the study. The population of the study was published between the dates January 2016-2017, and was compiled by making searches with the keywords "graphic designer" and "visual communication designer" from all industries across Turkey. Based on the data, how the professions are considered with regard to the industries, qualities and skills required for professions, expected qualities and skills of designers by industries, graduation statuses of professions etc are going to be analyzed using relational model; causalcomparative model.

\section{Findings, Discussion}

It is thought that it is important to see the demographic expectations of the profession by starting from the announcements before going through comparative analyzes between qualifications of job advertisements. In this context, seeing the priorities for job candidates to practice their profession will be provided.

Figure 1: General expectations of the positions in the job advertisements

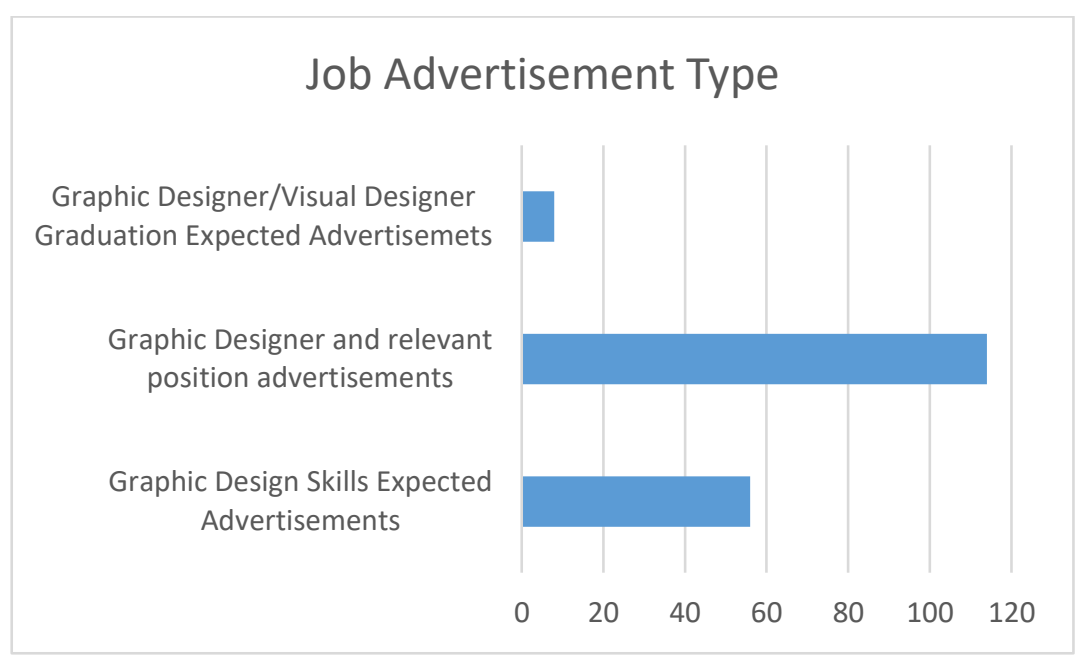

Figure 2: Degree of job position

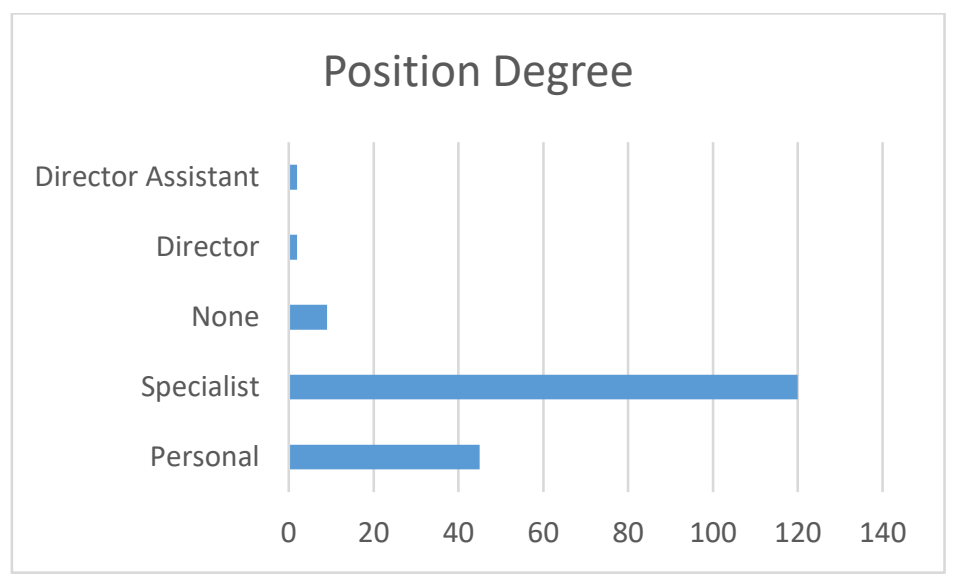

When general expectations of positions in job advertisements are addressed, while the occupational title for the position of the Graphic Designer is more highly preferred, it is a matter of considerable importance to search only with the profession's skillful features. Announcements 
with graduation focus are quite low value.

When the degrees of job positions are examined, it is thought that graphic designers are employed in more specialized or staff positions of job advertisements because they are the technical staff by job's nature.

Figure 3: Gender preferences for job

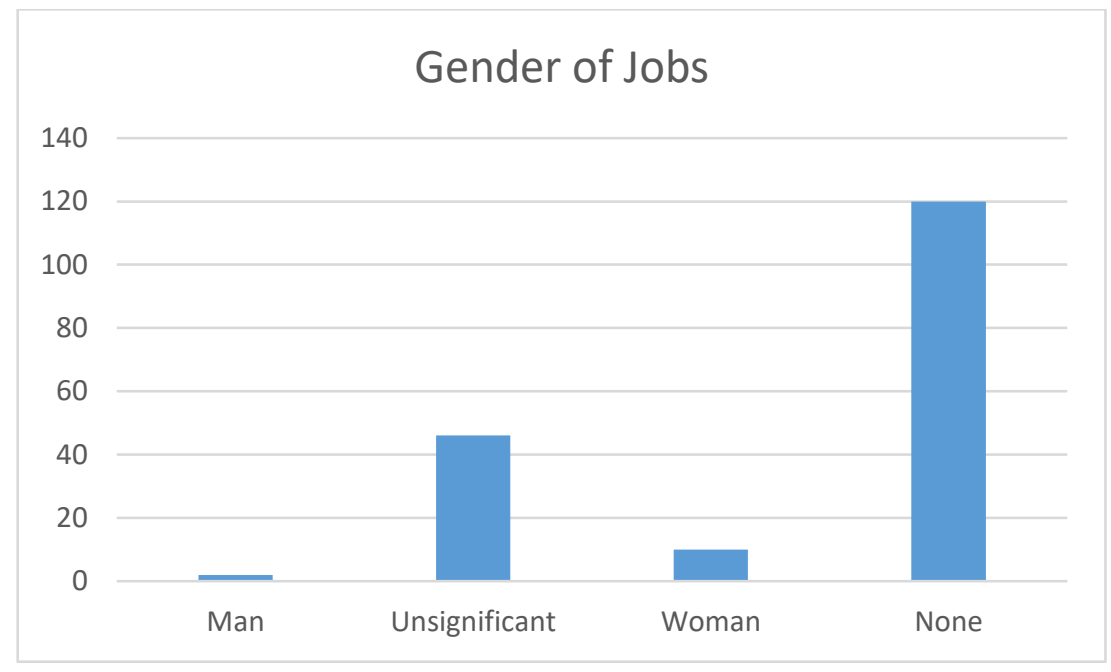

While it seems that there is no specific preference in terms of gender in the job positions based on the profession, the preference of female employees in the $8 \%$ is remarkable. Additionally, considering the information about the working time, $97 \%$ were found to be full time, $2 \%$ part time and $1 \%$ project-based.

Considering the competencies required by the job:

- Suitability for teamwork in the $95 \%$,

- Having completed military service in the $87 \%$,

- $\quad$ Suitability for flexible working hours in the $61 \%$ were encountered in the job advertisements.

- Not to smoking cigarette, having a driver's license and having no restriction to travel draw attention in the range of $2-10 \%$.

Figure 4: Number of values in age range

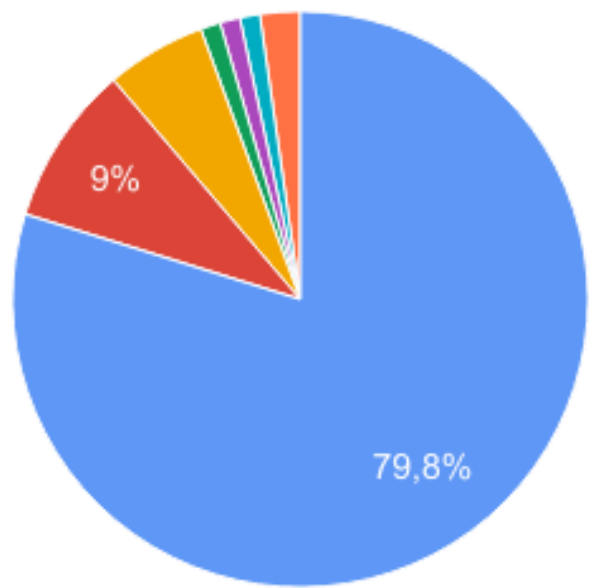


As with many professional qualifications, the age factor also creates employment concerns, especially for newly graduated candidates. The required age range in the advertisements is a range of $18-25$ years with a value of $79.8 \%$, and a range of $26-35$ years with a value of $9 \%$. Young professionals are preferred in terms of employment. The perception that young candidates who are newly graduated and who are still in the sector in terms of experience may have priorities in employment may be given.

Figure 5: Number of experience values

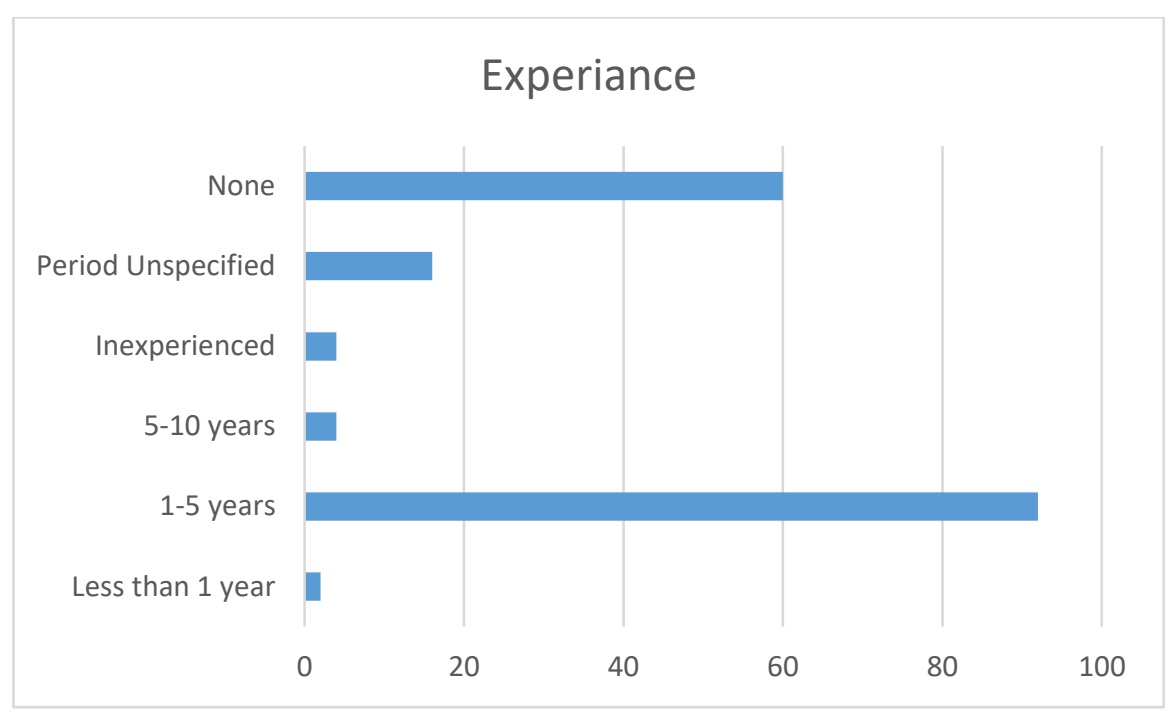

The fact that the age range in Figure 5 targets young people as employment requires the examination of experience expectations as well. Considering the values related to the experience in the advertisements, while $51 \%$ of these look for an experience of 5 to 10 years, $6 \%$ look for an experience of 5 to 10 years and $11 \%$ look for an experience even though the years are not specified. $31 \%$ of the advertisements do not require any experience. The mutual interpretation of these values reveals the perception that young people have the convenience of employment in the profession. Age and experience balance show a significant distribution in the advertisements. However, it can be said by looking at the Figure values, that the industry gives importance to experience in the recruitment even if just a bit and although varying from year to year.

Figure 6: Comparison of advertisement positions and advertisement types

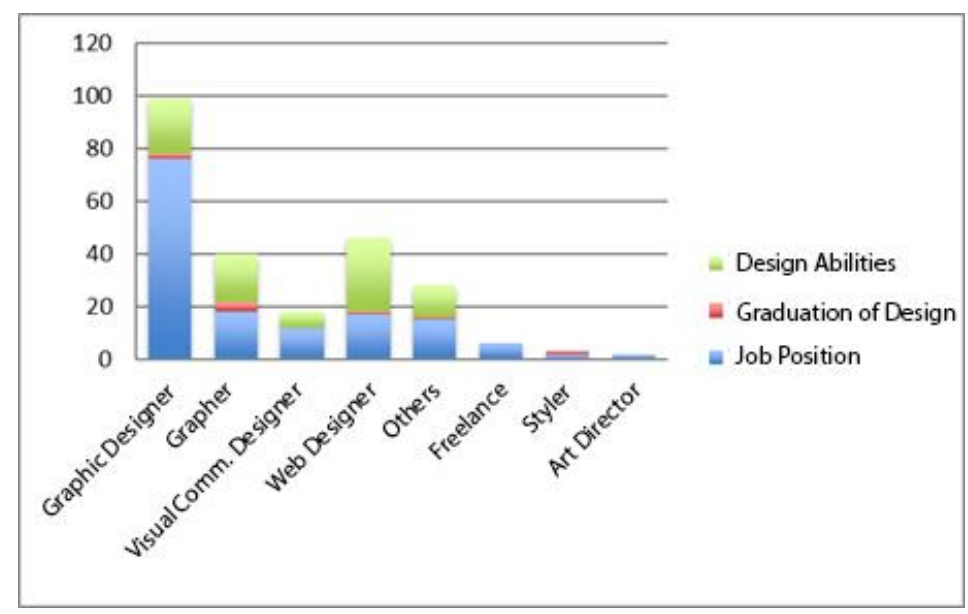

When the positions of job announcements are compared to the job announcement types, design graduation as a professional is not regarded as a necessary feature. 
- In the general approach, the designer's employment position is in demand.

- Especially in web designers, the rate of design skill have high importance.

It seems that graduation from the field is not important in the positions of art director and visual communication designer.

Figure 7: Comparison of job quality and gender

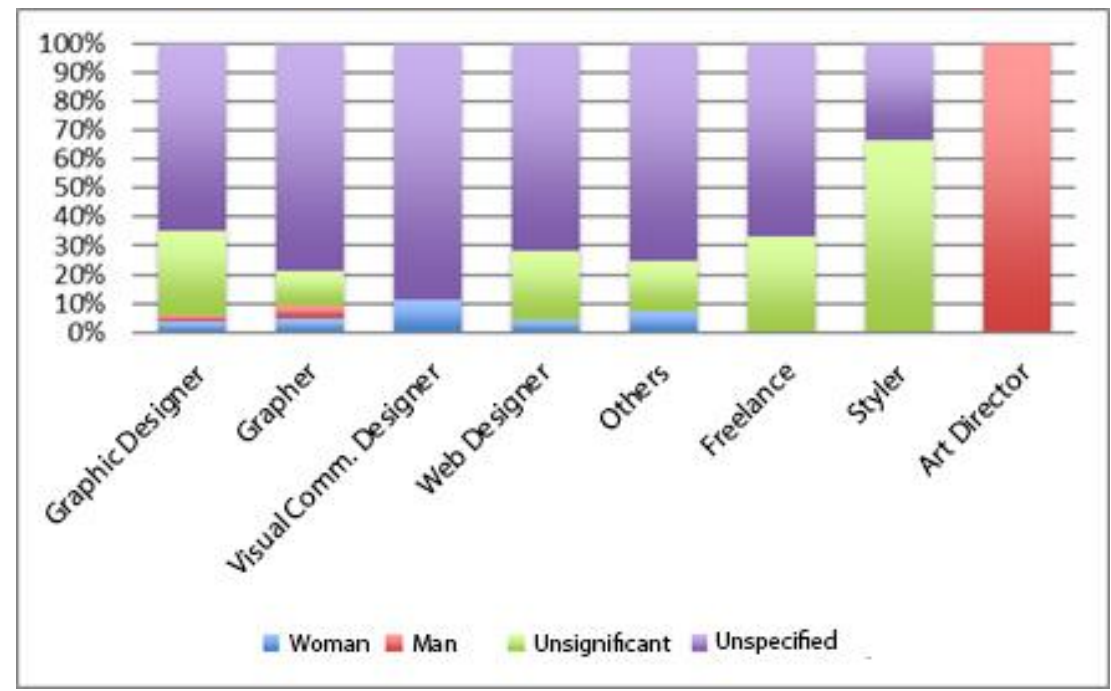

When job characteristics distributions and gender data are compared, female employment is more preferably indicated than male employment. Freelance and designer professions do not seem to have sex preferences. It is seen that only female employment is preferred for visual communication designer poisiton. However, it is seen that only male employment is preferred for the manager positions and for the art director title in the leadership of the creative team.

Figure 8: Comparison of general expectations in job position and sector

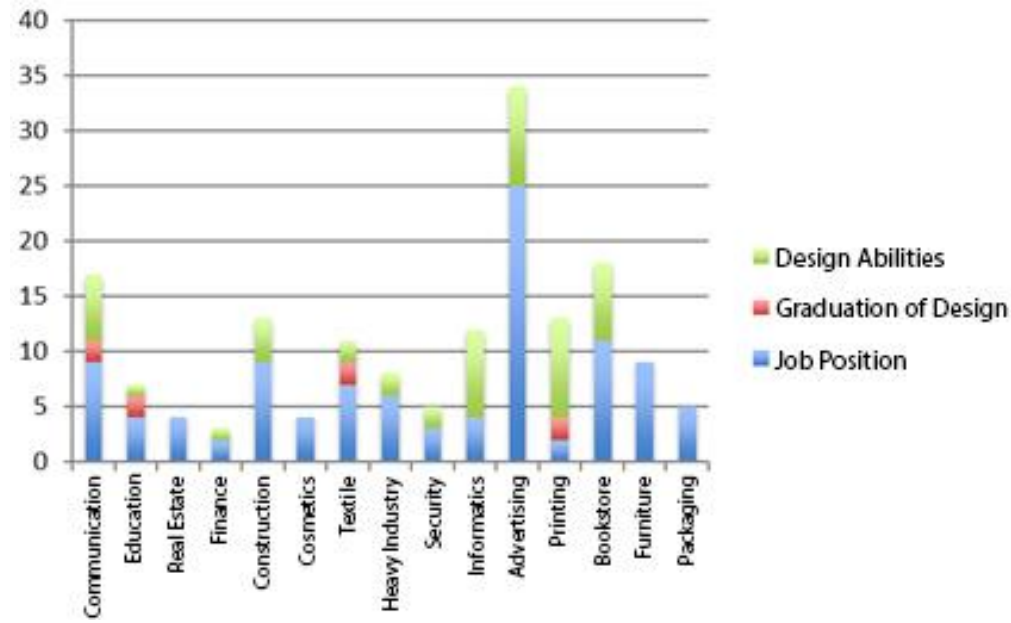

Considering the job advertisement data by sectors, job position is generally seen in high position. In sectors such as communication, advertising, printing, and bookstore, the expectation of design skill is higher. In the communication, education, textile and printing sectors, design graduation expectation seems significant compared to other sectors. The fact that there is no graduation expectation in the field of advertising having the most frequent employment and where 
the most sectoral advertisements are given is a remarkable situation.

Figure 9: Graduation field - general expectations of job position

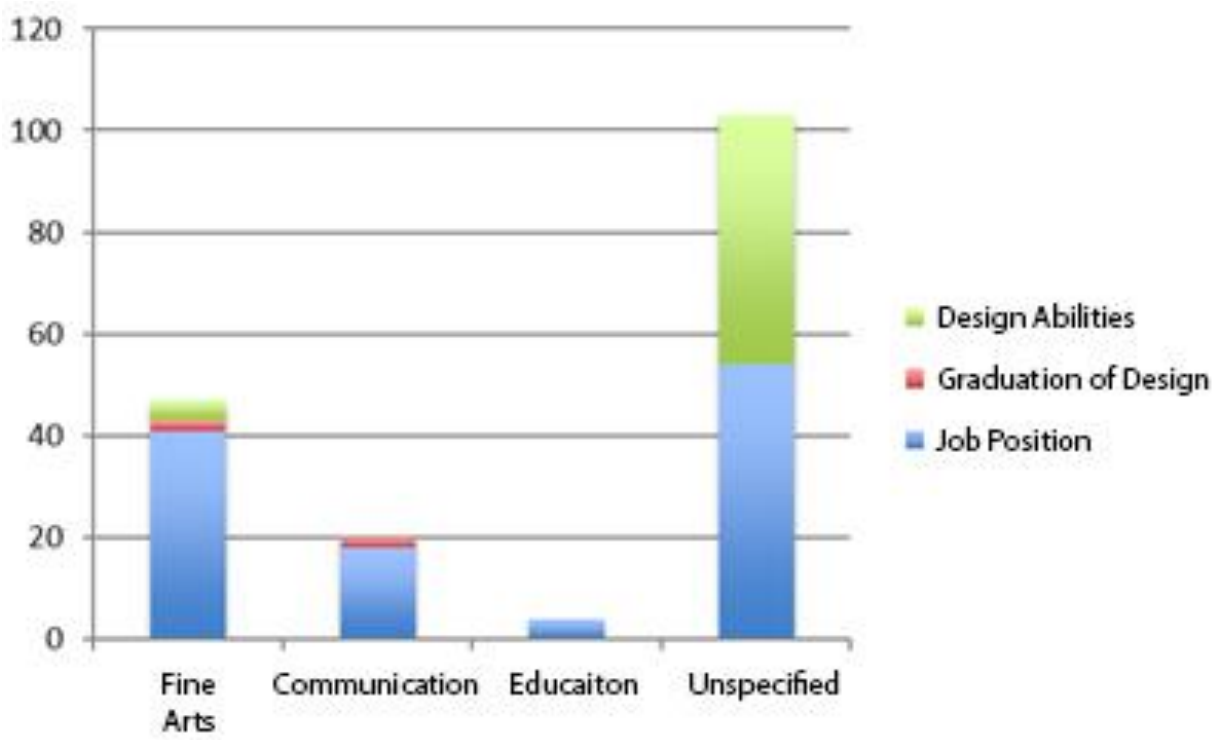

When academic graduation is compared to qualifications in job advertisement, it is seen that graduates from Fine Arts are preferred more for job positions. There is no expectation of design skill in the advertisements looking for graduates in communication field. Only suitability for position is sought for graduates from faculty of education. In other graduation fields (high school, vocational school, or non-art/design graduation), skill and suitability for position are significant.

Figure 10: Distribution diagram of occupational names by job expectations

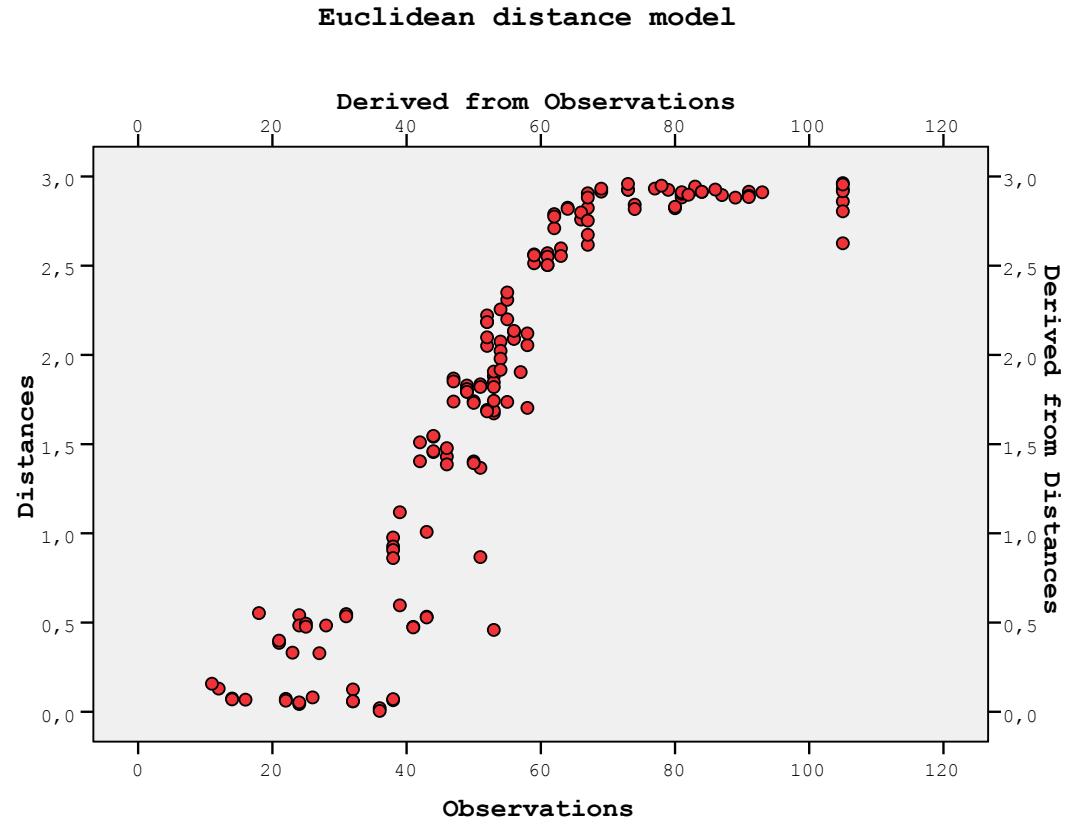

The diagram generated by the graphic designer job advertisements according to the observed and mapped distance values is as shown in Figure 10. Accordingly, while job expectation curve is 
close to the area of the characteristics of graphic designer job employment, it is mostly included in the area where the job advertisements on visual communication designer form a group and creates intensity in this area. Starting from this point, it can be said that the word graphic designer are more intense in job expectations and that the professional name visual communication designer draws attention. The density of graphic design work skills can be mentioned in the job expectation of visual communication design.

Table 1: Difference of Job Type by Sectors

\begin{tabular}{lrrrrr}
\hline & $\begin{array}{c}\text { Graphic } \\
\text { Designer }\end{array}$ & $\begin{array}{c}\text { Visual Communication } \\
\text { Designer }\end{array}$ & Grapher & $\begin{array}{c}\text { Web } \\
\text { Designer }\end{array}$ & $\begin{array}{c}\text { Communication } \\
\text { Designer }\end{array}$ \\
\hline $\begin{array}{l}\text { Chi- } \\
\text { Square }\end{array}$ &, 991 & 6,871 & 3,071 & 25,761 & 6,259 \\
Df & 1 & 1 & 1 & 1 & 1 \\
Asymp. &, 320 &, 009 &, 080 &, 000 &, 012 \\
Sig. &, & & & & \\
\hline
\end{tabular}

a Kruskal Wallis Test

b Grouping Variable: Difference of Job Type by Sectors

As in Table 1, there are differences in the distribution of job types by sectors. According to the groups of job advertisements where the role of job type differences is used as a determinant by sectors, the differences in the use of the definitions 'visual communication designer / natural background, communication designer / interior designer and web designer' among the background types have been identified. Accordingly, the titles 'visual communication designer $\left(X^{2}=6.871\right.$, $p=0.009)$ and communication designer $\left(X^{2}=6.259, p=0.012\right)$ ' were used in communication-oriented job advertisements in the groups where expectations were active, it was preferred as the title 'web designer' $\left(X^{2}=25.761, p=0.000\right)$ in the groups that require digital media domination (social media etc.) and multiple design qualities.

Figure 11: Distribution of job demands by sector

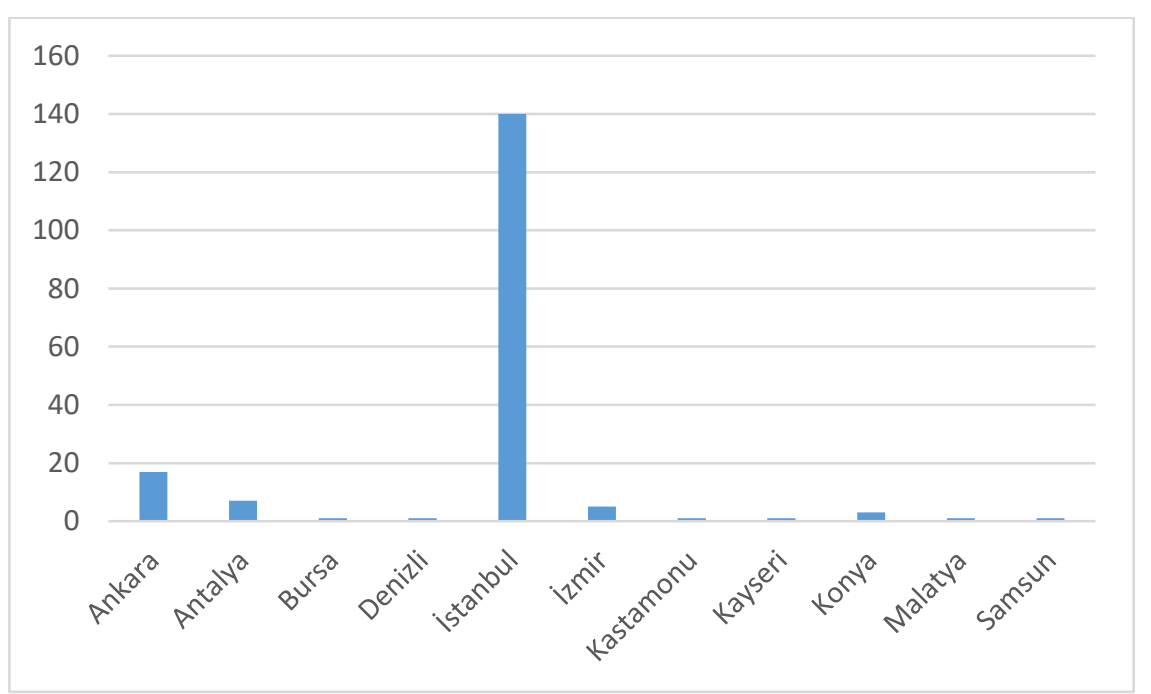

Considering the number of provinces where job advertisements are given, it is seen that Istanbul takes the lead with an important difference in figure 11. It is followed by Ankara, Izmir, Antalya and Konya. It is seen that occupational experts are also employed in sectors such as IT, Heavy Industry, Education and Construction, while Communication, Advertising and Printing have the priority by the job's nature in the sectoral distribution. Thus, it can be said that occupational experts are not only located in the institutions / organizations in communication and media sector, but also in the specific sectors. Thus, it can be mentioned that the business fields have expanded considerably for designers to practice their profession. 
Figure 13: Experience Expectation in the Sector

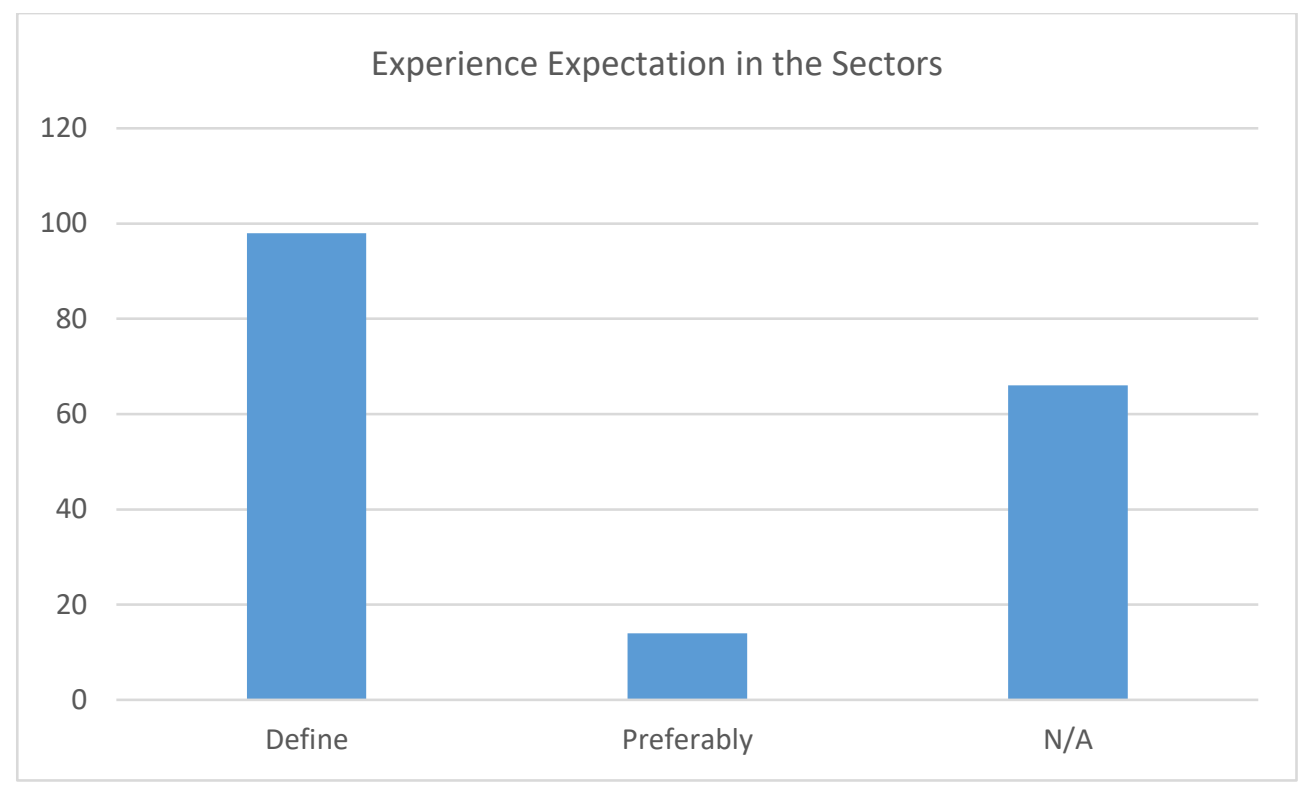

As can be seen in Figure 13, the expectation of sectoral experience in job advertisements is remarkable. Besides a definite experience condition, it is also expected that the candidates are preferably experienced at least. In general, since the age expectation is in the range of 26-35 years at the rate of $78 \%$, it can be considered that there is a direct relationship between experience and age. Additionally, as stated in the advertisements, designers are expected to have a command of Adobe Photoshop at the rate of $92 \%$ and plus Adobe Illustrator at the rate of $89 \%$. Apart from these programs, the use of Corel Draw program at the rate of $71 \%$ and Adobe InDesign software at the rate of $68 \%$ are also among the leading conditions. However, it should be noted that the softwares used in multi-media such as Adobe Flash, CCS, HTML, and Solidworks also attracted a small amount of attention among expections. Considering the world evolving into a digital age, having a command of digital media softwares will be among the expectations from graphic designers in the future.

Considering the special conditions of the advertisements, "having a command of design programs, suitability for flexible working hours, presenFigureness, suitability for team work, strong communication skills and job completion skills (coordination with print or digital solution partners)" are the primary and the most frequently used words respectively. These are followed by the words "work discipline, creativeness, and being open for improvement" as special conditions, respectively.

\section{Conclusion}

Because of the fact that the profession is not legally protected, individuals enter the sector in the same business area as academically graduated designers as a result of such compressed computer training and certification, and it is thought that this leads to an increase in the number of applications for employment, and even to competition. Here the employer's preferences play an important role. The budget allocated for this employment by the enterprise, the level of qualitative expectation, the ability of the designer, the experience, etc. are of decisive importance. The qualifications specified in the job advertisements also reveal the other qualities of a graphic designer with or without a formal academic education. Additionally, from the sectoral point of view, its relationship with graduation should also be considered as an important approach that should be examined in this study.

Although it is remarkable that graduation is important, it is also seen that the graduation status 
is not a priority in employment with a reflection of the budget policy of the business or sectoral structures. It is one of the remarkable points that besides the designer qualities, there are also different expectations from the people employed by the enterprises. For example, "having a command of design programs, creativeness, and being open for improvement" are the most common special conditions in the advertisements. It is foreseen that these facts may cause problems in the feature in terms of professional development, education and practice.

Legal protection of the profession is one of the most important concerns in this context, especially for academically educated designers who will be employed in the profession. Particularly, the fact that the aesthetic and artistic expectation of the sector is low profile leads to the devaluation of the diploma. As it is seen in these announcements, it is very thought-provoking that the definition of the profession is not even fully established and that the computer skills expected to be just a tool is put in the center of the business especially. The fact that issuer training centers such as the "Graphic Designer Vocational Course" focus solely on computer software and that there is no content about design education in the training curriculum of these courses lead to the decrease in the quality of those entering the sector. The supervision of such educational institutions by the academies and the issuance of the necessary certificates in cooperation with the universities are important in terms of the future place and reputation of the profession.

The evolution of sectoral expectations with technology is a common phenomenon in our day. So, as seen in the advertisements, the ability to use and manage digital media or multimedia are expected from graphic designers. In the future, it will be no longer an expectation but a skill that will be included in the sine qua non of the profession. Therefore, it is important to add relevant courses to the academic curricula and train specialist instructors in the relevant field.

Likewise, it seems likely that there will be other expectations of employment in the sector besides the graphic design skill, in the direction of employment of workers. These include skills such as "presenFigureness", "strong communication skills", "suitability for teamwork" and "ability to complete the job from start to finish". It is thought that these skills can be improved by updating curriculum contents in academic education process or by adding elective courses to curriculum by using different specialty branches (printing, web design, advertising, communication sciences etc.). Even the addition of current courses in which digital media instruments can be used more effectively and actively into programs in order to catch the age is one of the elements that enrich the design student.

Finally, it is assumed that the analysis of developments in the direction of the expectation of the profession about the sector with the regular analysis over the years will be very important in the updating of the vocational training. It is predicted that the next generation designers who will be trained thanks to the updated trainings by the rapidly changing global trends, the technologies and information will be able to enter the sector as well-appointed. The increase in the quality of the works produced by the designers who change themselves in a versatile way will lead those who enter this sector to always aim for the better and improve themselves. Of course, it is thought that these analyzes will shed light not only on educational institutions, but also on the professional designers working in the sector in terms of awareness of self-development.

\section{References}

Akdenizli, F. (2005). Türk Grafik Sanatlar Tarihinde Orijin Sorunu. Anadolu Sanat Dergisi, 16, 113123.

Akdenizli, F. (2017). Türkiye'de Grafik Tasarımcının Problemleri ve Bir Çözüm Ortağı Olarak Meslek Kuruluşları, Erişim Adresi http://www.tgdd.org.tr/makaleler/turkiyede-grafiktasarimcinin-problemleri-ve-bir-cozum-ortagi-olarak-meslekkuruluslari.html\#prettyPhoto

Anonim, Eli Acıman. (2016). https://tr.wikipedia.org/wiki/Eli_Acıman 
Arıkan, A. (2008). Grafik Tasarımda Görsel Algı. Konya: Eğitim Akademi Yayınları.

Becer, E. (1999). Iletişim ve Grafik Tasarım (2. Baskı). Ankara: Dost Yayınevi.

Berger, J. (2005). Görme Biçimleri. İstanbul: Metis Yayınları

Ersel, H. (2014). Türkiye'de Grafik Tasarım ve Afiş Eğitiminin Tarihine Kısa Bir Bakış. Kazım Taşkent Yapı Kredi ve Kültür Sanat, İstanbul: Yapı Kredi Yayınları.

Harris, P. and Ambrose, G. (2012). Grafik Tasarımın Temelleri (Çev.: Mehmet Emir Uslu). İstanbul: Liteatür Yayıncılık.

Lupton, E. (2012) "Neden Kuram", Grafik Tasarım Kuramı ( Ed. Helen Armstorng, Çev.: Mehmet Emir Uslu). İstanbul: Espas Yayınları.

Öztuna, H. Y. (2007) Görsel Iletişimde Temel Tasarım (Birinci Baskı). İstanbul: Tibyan Yayınıcılık.

Selamet, S. (2011). Türk Grafik Sanatlar Tarihine Alternatif Bir Yaklaşım: Osmanlı'dan Grafik Yansımalar. Marmara Iletişim Dergisi, 18, 239-251.

Selamet, S. (2012). Sürdürülebilirlik ve Grafik Tasarım. Zonguldak Karaelmas Üniversitesi Sosyal Bilimler Dergisi, 8(15), 125-148.

Twemlow, A. (2016) Grafik Tasarım Ne Içindir? (Çev.: Dalsu Özgen, ikinci Baskı). İstanbul: Yapı Endüstri Merkezi Yayınları. 
